\title{
HUBUNGAN ANTARA SIKAP IBU PRIMIPARA DENGAN PERKEMBANGAN ANAK USIA 1-3 TAHUN DI PUSKESMAS GARAWANGI KABUPATEN KUNINGAN
}

\author{
${ }^{1}$ Russiska, ${ }^{2}$ Atin Siti Ahyatin \\ ${ }^{1}$ Sekolah Tinggi Ilmu Kesehatan Kuningan, ${ }^{2}$ Puskesmas Japara \\ russiska88@gmail.com
}

\begin{abstract}
Abstrak
Masa balita merupakan dasar pembentukan kepribadian anak, sehingga memerlukan perhatian yang khusus untuk optimalisasi perkembangannya. Proses perkembangan anak biasanya ditandai dengan adanya perkembangan kognitif, perkembangan motorik dan perkembangan personal-sosial. Setiap aspek perkembangan saling berhubungan satu sama lain, apabila ada gangguan perkembangan pada salah satu aspek perkembangan maka dapat mempengaruhi aspek perkembangan lainnya. Oleh karena itu pemantauan perkembangan anak perlu dilakukan sejak dini. Peran ibu sangat penting dalam melakukan stimulasi perkembangan anaknya. Pemahaman yang baik dari ibu dapat membantu proses stimulasi perkembangan anak. Tujuan penelitian dapat mengetahui hubungan antara sikap ibu primipara dengan perkembangan anak usia 1-3 tahun di Puskesmas Garawangi Kabupaten Kuningan. Metode penelitian analitik dengan rancangan korelasional. Teknik pengambilan sampel menggunakan Stratified Random Sampling sebanyak 70 responden. Instrumen yang digunakan berupa kuesioner KPSP untuk perkembangan. Analisis data menggunakan korelasi Spearman Rank. Hasil analisis univariat Sikap ibu sebagian besar mendukung sebanyak 60 responden $(85,7 \%)$, Perkembangan sebagian besar sesuai usia sebanyak 54 anak $(77,1 \%)$. Hasil analisis bivariat, didapatkan nilai $\mathrm{p}=0,001$ ( $\mathrm{p}<0,05)$. Sehingga dapat disimpulkan bahwa ada hubungan antara sikap ibu primipara dengan perkembangan anak. Saran untuk tenaga kesehatan khususnya bidan dapat meningkatkan konseling, penyuluhan, membuat media promosi (leaflet) cara stimulasi perkembangan anak pada ibu primipara agar pengetahuannya bertambah sehingga membangun sikap yang mendukung perkembangan anak usia 1-3 tahun dan ibu primipara melakukan stimulasi kepada anak sesuai usianya.
\end{abstract}

Kata Kunci $\quad$ : Perkembangan Anak, Sikap, Ibu Primipara 
JURNAL OF MIDWIFERY CARE:

VOL. 01 NO. 02, JUNI 2021

DOI: $10.34305 / \mathrm{jmc} . \mathrm{V} 1 \mathrm{i} 02.267$

\section{Pendahuluan}

Anak dengan usia 1-3 tahun merupakan masa kritis dari perkembangan anak dan salah satu periode yang paling dinamis dan menarik. Pada masa ini anak mengalami berbagai macam perkembangan dari berbagai segi yang sangat optimal. Proses perkembangan anak biasanya ditandai dengan adanya perkembangan kognitif, perkembangan motorik dan perkembangan personal-sosial. Perkembangan ini saling berhubungan satu sama lain, apabila ada gangguan perkembangan pada salah satu aspek maka dapat mempengaruhi aspek lainnya. Oleh karena itu, pemantauan perkembangan perlu dilakukan sejak dini agar dapat segera mengenali gangguan perkembangan. Stimulasi diberikan secara berkesinambungan, dengan kasih sayang, metode bermain dan lain-lain (Soedjatmiko S, 2011).

Data angka kejadian keterlambatan perkembangan umum belum diketahui dengan pasti, namun diperkirakan sekitar 1$3 \%$ anak di bawah usia 5 tahun mengalami keterlambatan perkembangan (IDAI, 2013). Apabila gangguan perkembangan tidak ditangani, maka gangguan ini dapat berlanjut hingga dewasa dan sifatnya dapat menetap. Perkembangan anak erat kaitannya
Ciptaan disebarluaskan di bawah

Lisensi Creative Commons Atribusi-

NonKomersial-BerbagiSerupa 4.0

Internasional.

dengan peran orangtua terutama ibu dalam memberikan stimulasi. Pengetahuan dan pemahaman ibu dalam perkembangan anak dapat membantu dalam melakukan stimulasi, tetapi bagi ibu yang baru memiliki anak terkadang belum paham dalam melakukan stimulasi perkembangan pada anaknya (Hawadi, 2008).

Berdasarkan hasil wawancara dengan Ny. A petugas bagian tumbuh kembang Puskesmas Garawangi, tidak pernah dilakukan penyuluhan tentang perkembangan anak kepada ibu yang memiliki anak batita, hanya memberikan konseling jika ada ibu yang bertanya tentang perkembangan anak. Hasil studi pendahuluan yang dilakukan pada 10 orang ibu primipara sebagian besar tidak mengetahui bagaimana cara melakukan stimulasi perkembangan anaknya.

Berdasarkan uraian diatas, tertarik untuk melakukan penelitian dengan judul "Hubungan Sikap Ibu Primipara Dengan Perkembangan Anak Usia 1-3 Tahun di Puskesmas Garawangi Kabupaten Kuningan”

\section{Metode}

Jenis penelitian menggunakan analitik dengan pendekatan korelasional. Populasi dalam penelitian ini adalah seluruh 
JURNAL OF MIDWIFERY CARE:

VOL. 01 NO. 02, JUNI 2021

DOI: $10.34305 / j m c . v 1 i 02.267$

ibu primipara yang mempunyai anak batita sebanyak 235 responden. Teknik sampel menggunakan stratified random sampling sebanyak 70 responden.

Instrumen yang digunakan berupa kuesioner, untuk variabel sikap dengan jumlah 20 soal dan variabel perkembangan menggunakan KPSP (Kuesioner Pra Skrining Perkembangan) yang disesuaikan
Ciptaan disebarluaskan di bawah Lisensi Creative Commons AtribusiNonKomersial-BerbagiSerupa 4.0 Internasional.

dengan umur anak. Analisis data menggunakan analisis univariat dan bivariat dengan menggunakan spearman rank.

\section{Hasil}

Hasil analisis hubungan sikap ibu primipara dengan perkembangan anak usia 1-3 tahun di Puskesmas Garawangi Kabupaten Kuningan disajikan dalam tabel berikut ini:

Tabel 1. Hasil Analisis Univariat

\begin{tabular}{lcc}
\hline \multicolumn{1}{c}{ Variabel } & Frekuensi (f) & Persentase (\%) \\
\hline Sikap Ibu & & \\
Mendukung & 60 & 85,7 \\
Kurang Mendukung & 10 & 14,3 \\
Total & 70 & 100 \\
\hline Perkembangan Anak & & \\
Sesuai & 54 & 77,1 \\
Meragukan & 14 & 20 \\
Penyimpangan & 2 & 2,9 \\
Total & 70 & 100 \\
\hline
\end{tabular}

Sumber : Hasil Penelitian

Tabel 2. Hasil Analisis Bivariat

\begin{tabular}{|c|c|c|c|c|c|c|c|c|c|}
\hline \multirow{3}{*}{ Sikap } & \multicolumn{6}{|c|}{ Perkembangan } & \multirow{2}{*}{\multicolumn{2}{|c|}{ Total }} & \multirow{3}{*}{ P-Value } \\
\hline & \multicolumn{2}{|c|}{ Sesuai } & \multicolumn{2}{|c|}{ Meragukan } & \multicolumn{2}{|c|}{ Penyimpangan } & & & \\
\hline & $\mathrm{N}$ & $\%$ & $\mathrm{~N}$ & $\%$ & $\mathrm{~N}$ & $\%$ & $\mathrm{~N}$ & $\%$ & \\
\hline Mendukung & 52 & 74,2 & 8 & 11,4 & 0 & 0 & 60 & 100 & 0001 \\
\hline Kurang Mendukung & 2 & 2,9 & 6 & 8,6 & 2 & 2,9 & 10 & 100 & 0,001 \\
\hline
\end{tabular}

Sumber : Hasil Penelitian

Berdasarkan hasil penelitian, perkembangan anak usia 1-3 tahun dengan didapatkan $87.5 \%$ ibu primipara memiliki nilai $\mathrm{p}=0,001(\mathrm{p}<0,05)$. sikap mendukung dalam perkembangan anak. Perkembangan anak diperoleh sebagian besar perkembangan nya sesuai dengan usia $(77,1 \%)$. Hasil penelitian bivariat menunjukan bahwa ada hubungan antara sikap ibu primipara dengan

\section{Pembahasan}

\section{Analisis Univariat}

Ibu primipara memiliki sikap mendukung dalam perkembangan anak. Hal ini sejalan dengan penelitian yang dilakukan 
JURNAL OF MIDWIFERY CARE:

VOL. 01 NO. 02, JUNI 2021

DOI: $10.34305 / \mathrm{jmc} . \mathrm{v} 1 \mathrm{i} 02.267$
Ciptaan disebarluaskan di bawah

Lisensi Creative Commons Atribusi-

NonKomersial-BerbagiSerupa 4.0

Internasional.
Marni (2013), sebagian sikap ibu mendukung dalam perkembangan anak. Hal ini terjadi karena ibu memiliki sikap positif dalam perkembangan anaknya dan selalu memberikan stimulasi dini serta mendapatkan motivasi dari lingkungan sekitarnya. Ada pula ibu primipara yang mempunyai sikap kurang mendukung dalam perkembangan anak $(14,3 \%)$ karena mereka tidak mengetahui bagaimana cara mendeteksi.

Perkembangan yang sesuai ini menunjukan bahwa anak mendapatkan perawatan, pengasuhan yang baik dan stimulasi dini dari ibu dan keluarga. Para peneliti di Amerika Serikat menunjukkan bahwa anak yang tidak banyak distimulasi maka otaknya akan lebih kecil 30 persen dibandingkan anak lain yang mendapatkan rangsangan secara optimal. Untuk itu diperlukan penilaian dalam mendeteksi perkembangan anak agar dapat diketahui lebih dini bila ada gangguan dalam perkembangan anak (Diana, 2013).

\section{Analisis Bivariat}

Sikap dibentuk dari beberapa komponen dan membentuk sikap yang utuh. Pengetahuan, pikiran, keyakinan dan emosi memegang peran penting. Dalam pikiran, emosi dan keyakinan ibu memberikan respon sikap yang positif pada anaknya dalam berkomunikasi dan menstimulasi sehingga ibu selalu merespon positif terhadap perkembangan anaknya (Wawan \& Dewi, 2011).

Menurut Notoatmodjo (2011), proses perkembangan anak ditentukan dari oleh beberapa faktor yang saling berhubungan dengan proses perkembangan baik secara langsung maupun tidak langsung. Salah satu faktor yang mempengaruhi perkembangan seorang anak adalah sikap ibu. Kondisi sikap ibu dalam mengasuh anaknya mempunyai pengaruh yang sangat besar dalam perkembangan seorang anak. Dimana latar belakang pendidikan, pengetahuan, sikap dan keadaan ibu yang bekerja berakumulasi dalam membentuk perkembangan seorang anak.

Hal ini sejalan dengan hasil penelitian yang dilakukan oleh Marni (2013), dalam penelitiannya yang menyatakan sikap orang tua mempengaruhi cara memperlakukan anak dan keperluan orang tua terhadap anak sebaliknya mempengaruhi sikap anak terhadap orang tua dan perilaku orang tua. Jika sikap orang tua menguntungkan, hubungan orang tua dan anak akan jauh lebih baik ketimbang bila sikap orang tua tidak positif. 
JURNAL OF MIDWIFERY CARE:

VOL. 01 NO. 02, JUNI 2021

DOI: $10.34305 / \mathrm{jmc} . v 1 \mathrm{i} 02.267$

Ibu yang mempunyai sikap kurang mendukung $(2,9 \%)$ memiliki anak dengan penyimpangan perkembangan, hasil wawancara dengan ibu primipara yang anaknya mengalami penyimpangan perkembangan, hal ini karena ibu jarang sekali melakukan stimulasi pada anaknya. Anak lebih banyak disuruh untuk tidur dan bermain sendiri dengan mainannya. Ibu berpendapat dengan anak yang sering tidur itu baik untuk kesehatan anak. Ibu juga tidak tahu bagaimana cara melakukan stimulasi pada anak agar perkembangan anak sesuai dengan usia.

Sikap ibu primipara berperan penting dalam pemberian stimulasi, dengan kurangnya pengetahuan tentang cara melakukan stimulasi dapat memperlambat proses perkembangan anak. Perkembangan yang terlambat berbahaya bagi penyesuaian sosial dan pribadi anak yang baik. Selain itu akan terjadi juga bahaya yang lain yaitu harapan keterampilan yang tidak realistik, kegagalan mempelajari keterampilan yang penting bagi penyesuaian sosial dan pribadi anak. Maka dari itu, orang tua terutama ibu perlu melakukan stimulasi dan deteksi dini penyimpangan terhadap perkembangan anak (Soetjiningsih, 2018).
Ciptaan disebarluaskan di bawah Lisensi Creative Commons AtribusiNonKomersial-BerbagiSerupa 4.0 Internasional.

\section{Kesimpulan}

Berdasarkan hasil penelitian maka dapat dibuat kesimpulan sebagai berikut :

Sebagian besar ibu mempunyai sikap mendukung dalam perkembangan anak $(85,7 \%)$ dan sebagian besar anak mengalami perkembangan sesuai usia $(77,1 \%)$. Hasil uji spearman rank, terdapat hubungan antara sikap ibu primipara dengan perkembangan anak usia 1-3 tahun dengan nilai $p=0,001$.

Ibu primipara yang mempunyai anak dengan perkembangan normal maka hendaknya tetap mempertahankan pemberian stimulasi perkembangan, apabila perkembangan anak mengalami keterlambatan perkembangan maka hendaknya dapat meningkatkan pengetahuan tentang stimulasi dan frekuensi pemberian stimulasi sehingga perkembangan anak dapat berjalan dengan optimal.

Tenaga kesehatan khususnya bidan dapat meningkatkan konseling, penyuluhan dan membuat media promosi (leaflet) cara stimulasi perkembangan anak pada ibu primipara agar pengetahuannya bertambah dan membangun sikap yang mendukung dalam perkembangan anak usia 1-3 tahun dan ibu primipara dapat melakukan stimulasi kepada anak sesuai usianya. 


\section{Daftar Pustaka}

Diana, F. M. (2013). Omega 3 dan kecerdasan anak. Jurnal Kesehatan Masyarakat Andalas, 7(2), 82-88.

Hawadi. (2008). Pengantar Ilmu Kesehatan Anak Untuk Pendidikan Dini dan Kebidanan. Salemba Medika.

IDAI. (2013). Tumbuh Kembang Anak dan Remaja. Sagung Seto.

Marni. (2013). Hubungan Sikap Ibu Terhadap Perkembangan Anak Usia 13 Tahun (Toddler) di Sekolah Nisrina Jati Asih Kota Bekasi Tahun 2013. Sekolah Tinggi Ilmu Kesehatan Medistra Indonesia.

Notoatmodjo. (2011). Pengukuran Pengetahuan, Pendidikan dan perilaku Kesehatan. Rineka Cipta.

Soedjatmiko S. (2011). Deteksi Dini Tumbuh Kembang Balita.

Soetjiningsih, C. H. (2018). Perkembangan Anak Sejak Pembuahan Sampai dengan Kanak-Kanak Akhir: Seri Psikologi Perkembangan. Prenada Media.

Wawan, A., \& Dewi, M. (2011). Teori dan Pengkukuran Pengetahuan, Sikap Dan Perilaku Manusia: Yogyakarta. Nuha Medika. 